\title{
Trophic relationships between macroinvertebrates and fish in a pampean lowland stream (Argentina)
}

\author{
María V. López van Oosterom, Carolina S. Ocón, Florencia Brancolini, Miriam E. Maroñas, \\ Eduardo D. Sendra \& Alberto Rodrigues Capítulo
}

Instituto de Limnología “Dr. Raúl A. Ringuelet”, CCT - La Plata - CONICET, Universidad Nacional de La Plata (UNLP), Boulevard 120 y 62 s/n, (1900) La Plata, Buenos Aires, Argentina. (vanesa@ilpla.edu.ar)

\begin{abstract}
The diet and trophic relationships between the macroinvertebrates Phyllogomphoides joaquini Rodrigues Capitulo, 1992 and Coenagrionidae (Odonata), Chironomidae (Diptera), Diplodon delodontus (Lamarck, 1919) (Bivalvia: Hyriidae), and Pomacea canaliculata (Lamarck, 1822) (Gastropoda: Ampulariidae) and the fishes Pimelodella laticeps Eigenmann, 1917 (Heptapteridae) and Bryconamericus iheringii (Boulenger, 1887) (Characidae) in a temperate lowland lotic system in Argentina were assessed on the basis of gut contents and stable-isotope analyses. The feeding strategies were analyzed by the Amundsen method. Relative food items contribution for the taxa studied indicated a generalist-type trophic strategy. In macroinvertebrates, in general, the values of stable isotope confirmed the result of the analysis of gut contents. With the fish, stable-isotope analysis demonstrated that both species are predators, although $B$. iheringii exhibited a more omnivorous behaviour. These feeding studies allowed us to determine the trophic relationships among taxa studied. Detritus and diatoms were a principal source of food for all the macroinvertebrates studied. In La Choza stream the particulate organic matter is a major no limited food resource, has a significant influence upon the community.
\end{abstract}

KEYWORDS. Diet, stable isotope, temperate plain streams.

RESUMEN. Relaciones tróficas entre los macroinvertebrados y peces en un arroyo de la llanura pampeana (Argentina). Se evaluó la dieta y las relaciones tróficas entre los macroinvertebrados Phyllogomphoides joaquini Rodrigues Capítulo, 1992 y Coenagrionidae (Odonata), Chironomidae (Diptera), Diplodon delodontus (Lamarck, 1919) (Bivalvia: Hyriidae), Pomacea canaliculata (Lamarck, 1822) (Gastropoda: Ampulariidae) y los peces Pimelodella laticeps Eigenmann, 1917 (Heptapteridae) y Bryconamericus iheringii (Boulenger, 1887) (Characidae) en un ecosistema lótico pampásico, sobre la base del contenido estomacal y el análisis de isótopos estables. La estrategia alimentaria fue analizada mediante el método de Amundsen. La contribución relativa de cada categoría alimenticia para los taxa estudiados indicó que la estrategia predominante fue de tipo generalista. En general, en los macroinvertebrados, los valores de los isótopos estables confirmaron los resultados obtenidos por el análisis del contenido estomacal. En los peces, los isótopos estables demostraron que ambas especies son depredadores, aunque B. iheringii tiene un comportamiento más omnívoro. Además, el estudio de la alimentación, nos permitió establecer las conexiones tróficas entre los taxa estudiados. La principal fuente de alimento para los macroinvertebrados estudiados fueron el detritus y las diatomeas. En el arroyo La Choza la materia orgánica particulada es una fuente de recursos ilimitada con influencia significativa en toda la comunidad.

PALABRAS-CLAVE. Dieta, isótopos estables, arroyo templado de llanura.

Food webs are the trophic structures from which communities become organized according to the transfer of matter and its associated chemical energy. As such, food webs are a fundamental aspect of the dynamics of populations and communities. Stream-inhabiting invertebrates occupy all the trophic positions and thus form significant links between the basal resources and the predators of the top echelon (Allan \& Castillo, 2007). The classification of invertebrates into functional feeding groups (FFGs) based on the relevant foodgathering mechanism and food-type involved has proven an effective means of understanding the trophic relationships that occur within fluvial ecosystems (AlLAN \& CASTILlo, 2007). Macroinvertebrates constitute a major source of food for numerous fish (WALLACE \& WeBSTER, 1996) and are the most widespread and most extensively used food source for the fish of lotic systems (TOWNSEND, 1996).

A method employed for studying such trophic interactions is the analysis of gut contents since the latter usually represent the type of food available (AlLaN \& Castillo, 2007). In addition, the stable-isotope technique - it involving a measurement of increasing uses over the past two decades - constitutes a further tool of estimating the positions of organisms in the trophic chain, in order to identify food-web linkages and the sources of organic matter within ecosystems. The stable- $\mathrm{N}$ isotopic signature $\left(\delta^{15} \mathrm{~N}\right)$ in particular, is used to position the trophic level of a single member or group of organisms in a given food web because the $\delta^{15} \mathrm{~N}$ of a consumer becomes enriched relative to its prey (VANDER ZANDEN \& RASMUSSEN, 2001). Stable-carbon isotopes can indicate feeding and carbon-flow pathways because of the occurrence of little fractionation through the food web and since different energy sources can have differing $\delta^{13} \mathrm{C}$ values (DeNiro \& Epstein, 1981; Minagawa \& Wada, 1984; Peterson \& Fry, 1987; VANDer Zanden \& Rasmussen, 2001). The stable-isotope analysis of allochthonous and autochthonous foods - those usually differing in $\delta^{13} \mathrm{C}$-and of their consumers offers a promising potential for resolving issues arising from the River Continuum Concept (VANNOTE et al., 1980) and for examining the trophic basis of production in streams (LAU et al., 2009).

The knowledge of streams of the pampean plain is scarce and fragmental. Some specific studies have been made looking at diversity community for macroinvertebrate or fish assemblage (ALMIRón et al., 2000; Rodrigues CAPÍtulo et al., 2001, 2002, 2003, 2010; Di Marzio et al., 2003; Remes Lenicov \& 
Colautti, 2005; Fernández et al., 2008; Colautti et al., 2009), but no feeding studies nor of trophic relationships between these assemblages. For this reason, the objective of this paper was to analyze the diet of the macroinvertebrates and fish in a temperate pampean stream on the basis of gut content and then to compare those data with carbon and nitrogen stable-isotope analyses in order to determine the trophic relationships between consumers and the basal resources.

\section{MATERIALS AND METHODS}

Study area. The La Choza stream (Buenos Aires province, Argentina) is part of the upper Reconquista River basin. The watershed of this stream has a surface of 15,200 ha and features intense agricultural activity, with $64 \%$ of the area being used for cattle raising, $34 \%$ for extensive agriculture, and the remaining $2 \%$ divided between poultry farming and urban use (RoDRIGUES CAPítulo et al., 2010).

The La Choza is a $2^{\text {nd }}$ order stream characterized by a low slope $(<1 \%)$, a slow flow, a high turbidity, abundant organic matter, and an elevated content of suspended solids (Giorgi et al., 2005). The climate is temperate and humid with an annual average temperature of $18^{\circ} \mathrm{C}$ and an annual average rainfall of $900 \mathrm{~mm}$ (GIORGI et al., 2005). The predominant natural vegetation of Buenos Aires province is grassland. According to PARODI (1942) the intense competition of the grasses for water in periods of rainfall deficit would have impeded the establishment of hardwood trees within the region. Even in the upper-stream reaches, the absence of riparian vegetation, results in high levels of irradiance along the course, favoring the development of dense macrophyte stands and accompanying algal growth (FeIJoó \& Lombardo, 2007).

The heterogeneity of the La Choza environment, as well as the most pampean streams, resides not in the different types and sizes of the substrates present but rather in the diverse architecture of the aquatic plants that, for their part, shelter a rich and dense invertebrate community (Giorgi et al., 2005). Since the studied stream has an uniform bottom composed of fine sediments (primarily silt and clay), a single sampling site was established in the La Choza headwaters $\left(34^{\circ} 44^{\prime} 24^{\prime \prime} \mathrm{S}, 59^{\circ} 6^{\prime} 27^{\prime \prime} \mathrm{W}\right)$ for the collection of both macroinvertebrates and fish.

Sampling. The macroinvertebrates were sampled bimonthly for two years (2007- 2008). In each sampling date three replicates of benthic macroinvertebrates were removed with an Ekman grab $\left(100 \mathrm{~cm}^{2}\right)$; and for detecting nonbenthic macroinvertebrates, samples were taken using a square of $625 \mathrm{~cm}^{2}$ with sieves $(250 \mu \mathrm{m})$ from the macrophytes present. The samples were fixed in situ with $5 \%(\mathrm{v} / \mathrm{v})$ formaldehyde. In the laboratory, the samples were washed on a $250 \mu \mathrm{m}$ mesh sieve and the macroinvertebrates identified to the lowest possible taxonomic level under a stereomicroscope through the use of the taxonomic keys of Fernández \& DomíngueZ (2001).

The fish were collected in November 2007 and December 2008. At the sampling site, a $25 \mathrm{~m}$ segment of the stream channel was cordoned off with transverse enclosure nets $(10 \times 5 \mathrm{~mm}$ mesh size $)$. Within that perimeter, the capture of fish was done with a seine net (10 $\mathrm{mm}$ bar mesh size) containing a bag. The specimens collected were fixed in $10 \%(\mathrm{v} / \mathrm{v})$ formaldehyde and taxonomically classified in the laboratory.

Analysis of macroinvertebrate and fish gut contents. For analysis of the gut contents of the macroinvertebrates, the following taxa were selected: the Chironomidae (Diptera), Diplodon delodontus (Lamarck, 1919) (Bivalvia: Hyriidae), Pomacea canaliculata (Lamarck, 1822) (Gastropoda: Ampulariidae), Phyllogomphoides joaquini Rodrigues Capítulo, 1992 (Odonata: Gomphidae), and Coenagrionidae sp. 1 (Odonata), because they are commonly found in pampean streams (OCón \& ROdRIGUES CAPÍTULO, 2004; Rodrigues CAPÍtulo et al., 2010). The Odonata were the most abundant predator group along with Belostoma elegans (Mayer, 1871) (Hemiptera: Belostomatidae), but the latter species, because of its sucking form of alimentation, was discarded for the analysis of gut contents. Of each taxon, up to 10 individuals were dissected under the stereomicroscope for each sampling date. The foreguts were separated, their contents removed, and the latter placed in vials with Bengal's rose colorant for $24 \mathrm{~h}$. These samples were then transferred to distilled water and collected on 0.45 micron membranes. The membranes were clarified with immersion oil and 15 randomly selected fields per slide counted under a microscope at a 400x magnification. For each item, the area covered was measured with a graduate eyepiece and the relative abundance expressed in percent of the area occupied by the total gut contents (after WINTERBOURN et al., 1984; JAARSMA et al., 1998; DíAZ-VILLANUEVA \& Albariño, 1999).

From the fish assemblages we selected Pimelodella laticeps Eigenmann, 1917 (Siluriformes: Heptapteridae) and Bryconamericus iheringii (Boulenger, 1887) (Characiformes: Characidae) because both are characterized as permanent and abundant fish species of the stream (ColaUtTi et al., 2009). The gut content analysis was performed on the first third of the digestive tract. For P. laticeps, 21 stomachs from the 2007 and 18 from the 2008 samples were selected for study; for $B$. iheringii, the samplings were 15 and 17 stomachs for corresponding years. Stomach contents were identified to the lowest possible taxonomic category. We then applied a semiquantitative scale for the volume occupied by a particular trophic category, employing a code of 0 to 4 (0: absent; $1:<10 \% ; 2: 10 \%-25 \% ; 3: 25 \%-50 \%$; 4: $>50 \%)$

Data analyses of the gut contents. The feeding 
strategies of both the macroinvertebrates and the fish were analyzed by the graphic method of Costello, as amended by AMUNDSEN et al. (1996). This approach allows the acquisition of information on predator feeding strategy through the graphical representation of the prey-specific abundance of prey i (Pi) against the frequency of occurrence (Fi).

The percent abundance $(\mathrm{Pi})$ is calculated as:

$$
\mathrm{Pi}=\left(\frac{\sum \mathrm{S}_{\mathrm{i}}}{\sum \mathrm{St}_{\mathrm{i}}}\right) \times 100
$$

where:

$\sum \mathrm{S}_{\mathrm{i}}=$ the content of a prey $\mathrm{i}$ within all the stomachs $\sum \mathrm{St}_{\mathrm{i}}=$ the total content of the stomachs where the prey i appears

The frequency of occurrence $\left(\mathrm{FO}_{\mathrm{i}}\right)$ is obtained by the equation:

$$
\mathrm{FO}_{\mathrm{i}}=\left(\frac{\mathrm{N}_{\mathrm{i}}}{\mathrm{N}}\right) \times 100
$$

where:

$\mathrm{N}_{\mathrm{i}}$ = number of predators with the prey $\mathrm{i}$ in their stomachs $\mathrm{N}=$ total number of predators having stomach contents We have represented the trophic relationships among the taxonomic groups studied here by means of a diagram of interconnections. Each connection represents a foodbased interaction among the different taxa.

Functional feeding groups. The functional feeding groups (FFGs) assigned following the criteria of MerritT \& Cummins (1996), were: (1) the shredders (feeding on coarse particulate organic matter $>1 \mathrm{~mm}$ in size), (2) the filtering collectors (sifting fine particulates of 0.45 to $1 \mathrm{~mm}$ from the flowing column of water), (3) the gathering collectors (gathering fine particulates of organic matter from the debris and stream-bed sediments), (4) the scraper-grazers (scraping off and consuming the organic layer of algae, microorganisms, and dead organic matter attached to stones and other substrates), and (5) the predators (feeding on other animals). After identification, macroinvertebrates were assigned to a FFG using available literature (MERRITT \& Cummins, 1996; Cummins et al., 2005). The percentage of taxa in each FFG category was calculated. Those taxa that did not can be assigning to a single FFG, were not considered in the calculation. The taxa $P$. joaquini, Coenagrionidae sp.1, Chironomidae, D. delodontus, $P$. canaliculata were classified into FFGs based on the dominant food consumed (more than $60 \%$ of gut contents) according to our analyses.

Stable-isotope analysis. For the macroinvertebrates, several individuals of each selected taxon (in numbers depending on their weights) were collected. In the laboratory they were left for $24 \mathrm{~h}$ at room temperature until the gut contents had evacuated in order to include only assimilated substances in the analysis (in the case of molluscs the shells were discarded and the remaining body was processed). With the fish, the digestive tract was dissected out and discarded, while the remaining body was processed. The macroinvertebrates and fish were dried at $60^{\circ} \mathrm{C}$ to constant weight and ground into a powder to insure homogeneity. The resulting samples were weighed down to 3 or $4 \mathrm{~g}$, placed in capsules (MuÑoz et al., 2009), and analyzed by a Carlo Erba CHNS elemental analyzer coupled to a mass spectrometer (University of Barcelona, Spain). Isotopic ratios are typically expressed as the ratio of the high to low isotope and converted into delta notation ( $\delta$-values) through comparison of sample isotope ratios to ratios of internationally accepted standards. Standards for common systems include Vienna-Pee Dee Belemnite limestone (V-PDB) for carbon, atmospheric $\mathrm{N}_{2}$ for nitrogen.

The macrophyte, epiphyton, seston, fine particulate organic matter (FPOM) and coarse particulate organic matter (CPOM) $\mathrm{C}$ and $\mathrm{N}$ isotopes information used in the analysis were provided by Feijoó (unpublished data).

\section{RESULTS}

Amundsen diagrams support the generalist categorization for the macroinvertebrates studied feeding strategy with the exception of $D$. delodontus, which is a specialist, feeding on detritus (Fig. 1-5). The occurrence frequency of the detritus, diatoms, and mineral material in the gut contents were elevated in D. delodontus, $P$. canaliculata and Chironomidae, with the detritus being the most representative component ( $>$ $40 \%$, Figs 1-3). Diatoms were the second most prevalent content with the greatest abundance being found in the gut of the snail P. canaliculata (Fig. 2). Vascular plants were also a common item in this species. Animal remains were found in the Chironomidae in low frequency and abundance (Fig. 3). Animal remain exhibited a greater prevalence in $P$. joaquini and in the Coenagrionidae sp. 1. The identifiable taxa ingested by Coenagrionidae were Chironomidae, Cyclopodea and in low frequency and abundance other Odonata (Fig. 5).

The position of prey items in figures 6 to 9 indicated that both fish species exhibited a generalist strategy and the diversity of items was higher in spring 2007. The total number of items found on the two sampling occasions was 18 and 14 for $B$. iheringii and 28 and 12 for $P$. laticeps, respectively. For both species, the item Gastropoda exhibited a low FO, but a high abundance in the spring of 2007. The opposite pattern occurred with the item Collembola that showed high FO but low relative abundance in 2007. Unidentified remains of insects (larvae, pupae, nymph) and chironomid larvae were part of the diet in both these fish species and on the two sampling dates; and, together with other insects and their remains became the most significant components in the spring of 2008. The vegetable fraction was more frequently detected in $B$. iheringii, mainly in the form 


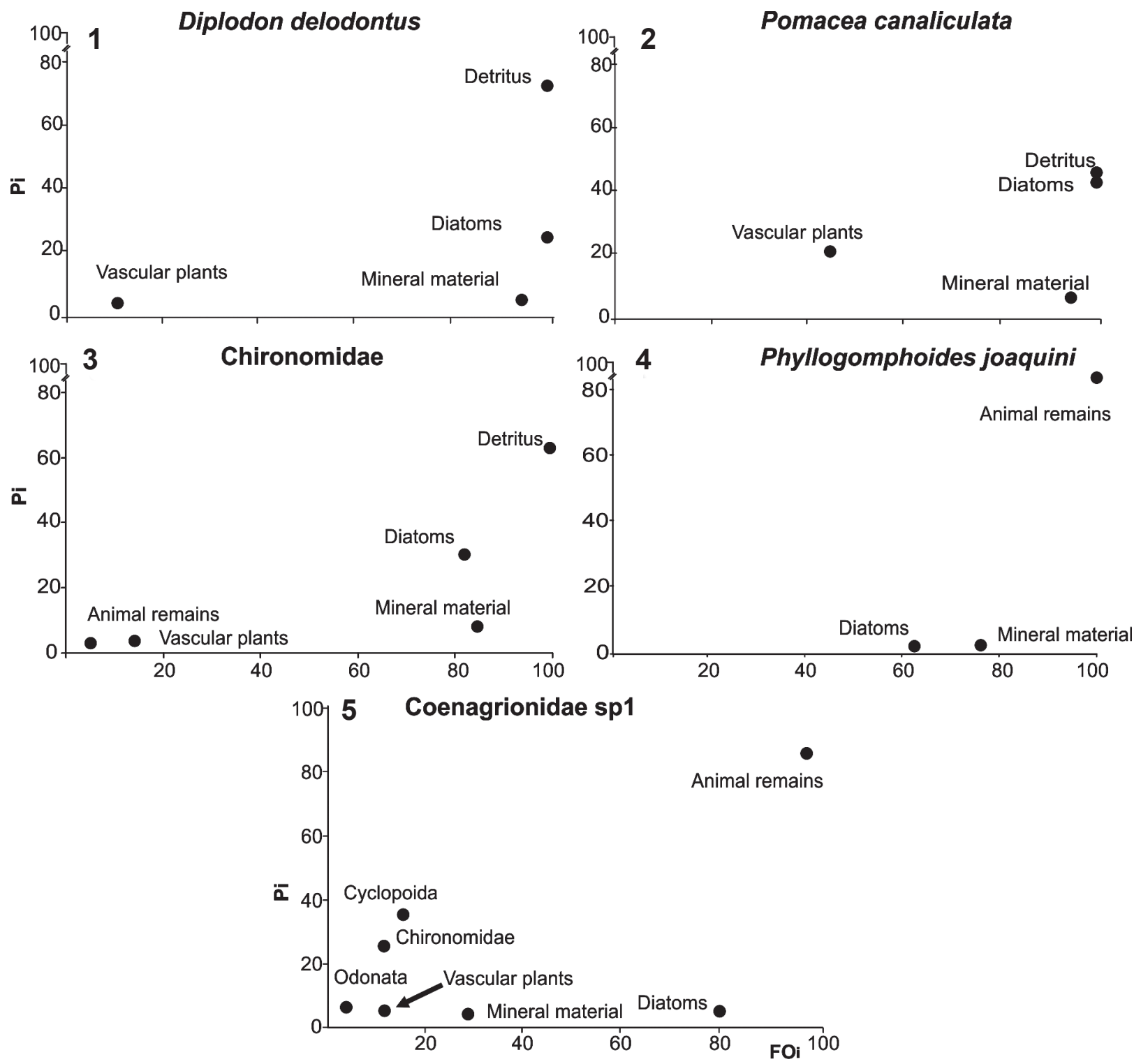

Figs 1-5. Amundsen diagrams for macroinvertebrate in La Choza stream during 2007-2008 (Pi, prey-specific abundance, in \%, of food item i; FOi, frequency of occurrence).

of a filamentous algal web that was often entwined with animal remains.

The diagram of the trophic relationships (Fig. 10) illustrates the prevalence of vascular plants, diatoms and detritus as a source of food for the macroinvertebrates. The longest food chain had two connections. The first is between the basal resources and the macroinvertebrates or fish, the second between the macroinvertebrates and the fish or predators macroinvertebrate. The Chironomidae was food source utilized by predator macroinvertebrate or fish. This figure also shows that $P$. laticeps exhibited the greatest number of trophic connections with the invertebrates, with $B$. iheringii accordingly presenting fewer, being more varied and important the vegetable fraction.

The figure 11 shows the prevalence of each FFG of La Choza stream macroinvertebrates assemblage.
The gathering collectors, representing nearly half of the taxa, were the predominant FFG, while the predators, the filtering collectors, and the scrapers constituted the remaining groups. Shredders were not present in any of the samples. Nematoda were not considered for analysis because the taxonomic resolution did not allow assigning them to only one FFG.

Based on the gut content analysis was determined that $D$. delodontus was found to be a filtering collector, $P$. canaliculata a scraper, Chironomidae gathering collector, while $P$. joaquini and Coenagrionidae sp. were predators.

The figure 12 shows the stable nitrogen and carbon isotopes in the taxonomic groups analyzed and in the basal resources available. The consumers isotopic signatures for nitrogen ranged from $9.7 \%$ ( $P$. canaliculata) to $14.0 \%$ ( $P$. joaquini), whereas 


\section{Bryconamericus iheringii}
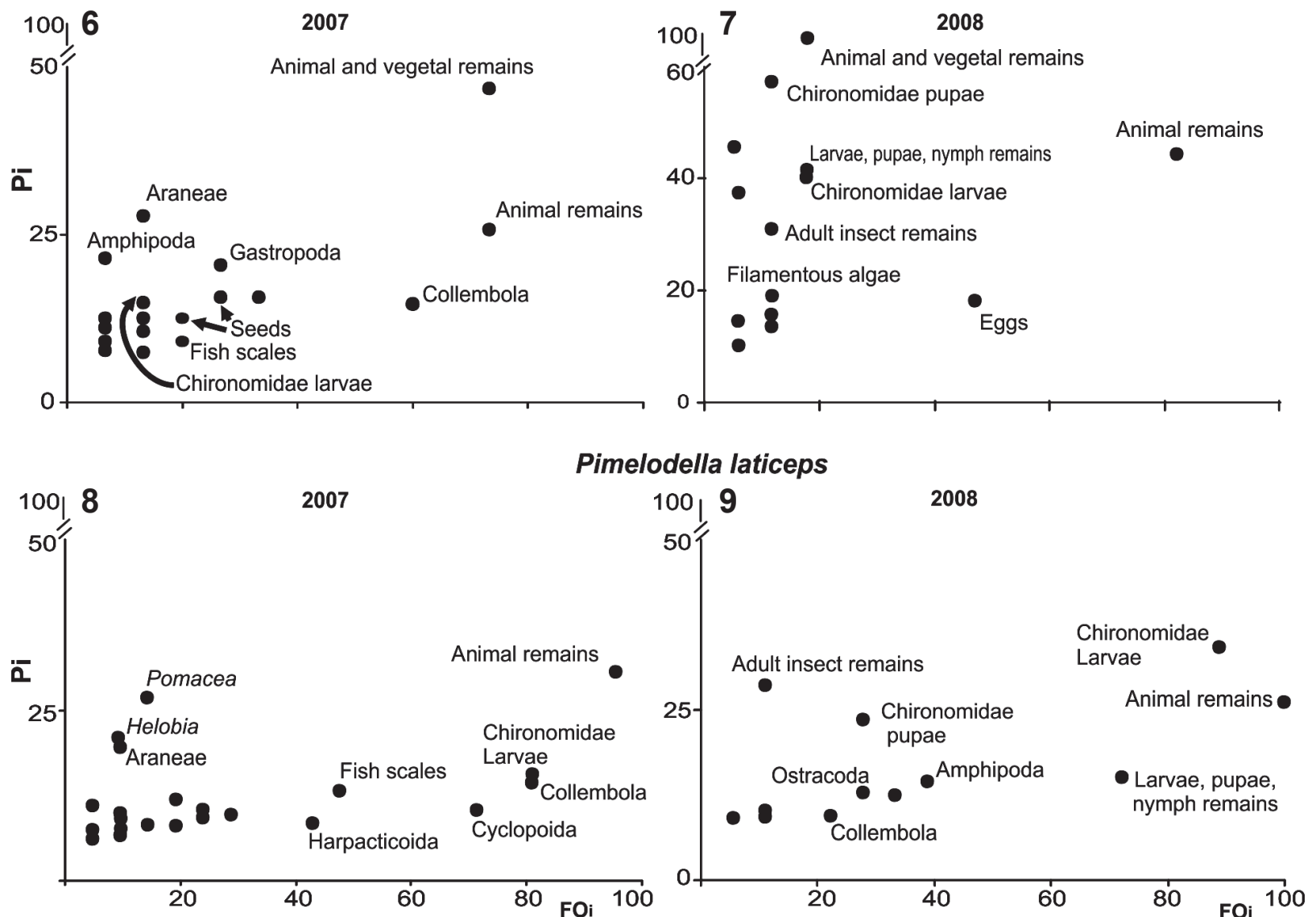

Figs 6-9. Feeding-strategy diagrams for each fish species and sampling year (2007-2008) in La Choza stream (Pi, prey-specific abundance, in \%, of food item i; FOi, frequency of occurrence).

the corresponding figures for carbon fell between $-27.8 \%$ (Coenagrionidae) and $-21.6 \%$ (B. iheringii). A comparison of the $\delta{ }^{13} \mathrm{C}$ values for the taxa with those of the basal resources indicated that the particulate organic material (both fine and coarse) was a Carbon resource for most taxa studied. Diplodon delodontus data was also consistent with the values $\delta{ }^{13} \mathrm{C}$ of seston and $P$. laticeps with macrophytes and epiphyton value. For $B$. iheringii the data corresponded with the values of epiphyton.

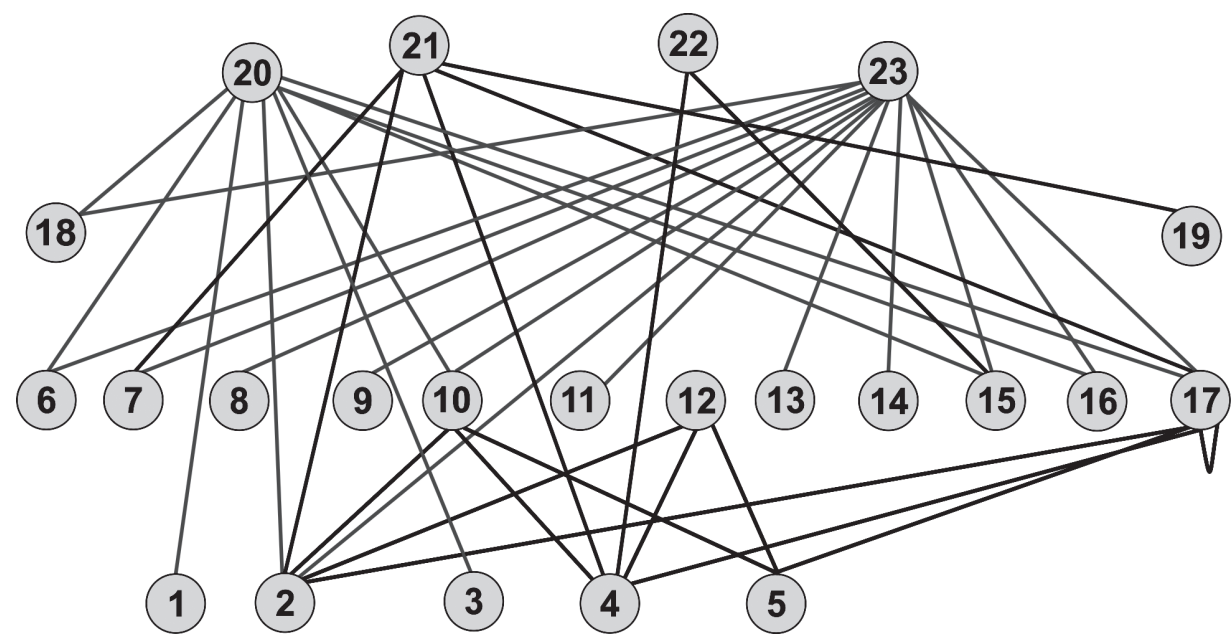

Fig. 10. Diagram of the connectivity of the trophic relations among the taxa studied in La Choza stream during 2007-2008. Food items are denoted by the corresponding numbers: 1 , seeds; 2 , vascular plants; 3 , filamentous algae; 4,diatoms; 5 , detritus; 6 , Amphipoda; 7 , Cyclopoida; 8 , Harpacticoida; 9, Ostracoda; 10, Pomacea canaliculata; 11, Planorbidae; 12, Diplodon delodontus; 13, Bivalvia; 14, Ephemeroptera; 15, animal remains; 16, Collembola; 17, Chironomidae; 18, Araneae; 19, Odonata; 20, Bryconamericus iheringii; 21, Coenagrionidae sp. 1; 22, Phyllogomphoides joaquini; 23, Pimelodella laticeps. Grey line: fishes connection; black line: macroinvertebrates connection. 


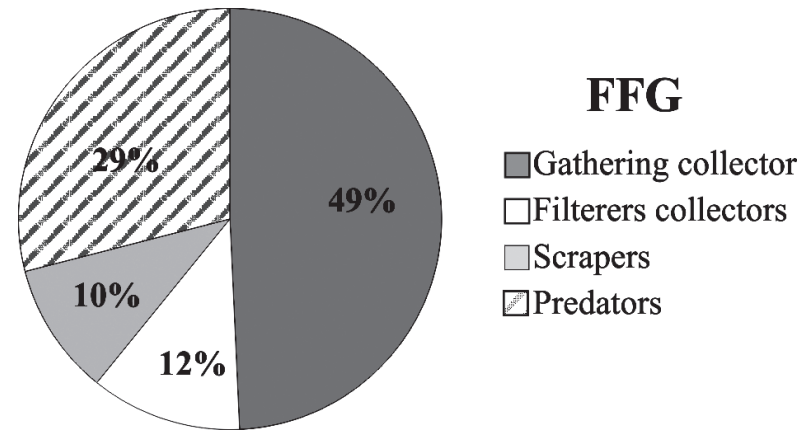

Fig. 11. Prevalence of each FFG among the macroinvertebrates of $\mathrm{La}$ Choza stream during 2007-2008 expressed as a percent of the total number of taxa present.

\section{DISCUSSION}

Diet studies allowed a determination of the trophic relationships among taxa studied. For the macroinvertebrates analyzed of La Choza stream, the feeding strategy was predominantly generalist, with the detritus being the most widely used resource for most taxa because of its abundance within the study area. MотTA \& UIEDA (2004) found similar results in a tropical river in Brazil having a high prevalence of organic matter as a food resource. No literature on the feeding habits of D. delodontus is currently available. In our work this bivalve differed from the other taxa in being a specialist; whose gut contents as recorded in the present analysis matched the items reported previously by LARA et al.
(2002) for Diplodon chilensis, a species with similar characteristics to those of the $D$. delodontus of $\mathrm{La}$ Choza stream. According to these authors, D. chilensis would be an alternative detritivorous filterer that fed mainly in the benthos (e.g., on microalgae, bacteria, and organic matter) and secondarily in the water column ( $e$ $g$., on microalgae and organic matter). Several authors studying the feeding of $P$. canaliculata (CAZZANIGA \& Estebenet, 1984; Estebenet 1995; EstebenET \& MARTIN, 2002) observed that the diet of that species included vascular plants, detritus, and at times animal remains. This organism was found to be primarily a macrophytophage, preferring the floating or submerged plants to the emergent ones (BONETTO \& TASSARA, 1987). In our analysis we observed that the detritus was the main dietary component followed in importance by vegetal matter and the diatoms. This snail is extremely polyphagous with a great plasticity that enables the utilization of a given abundant resource, such as organic matter (detritus), without desisting in feeding on aquatic vegetation. Berg (1995) reported the Chironomidae that consume five types of foods: algae, detritus (along with associated microorganisms), macrophytes, woody debris, and other invertebrates. In the present study we found a predominance of detritus, although the remains of animals were also found in the gut contents of some individuals as a result of the presence of predator organisms within the subfamily Tanypodinae. Diatoms that were observed in the intestinal contents of both Odonata could correspond to their preys consumed,

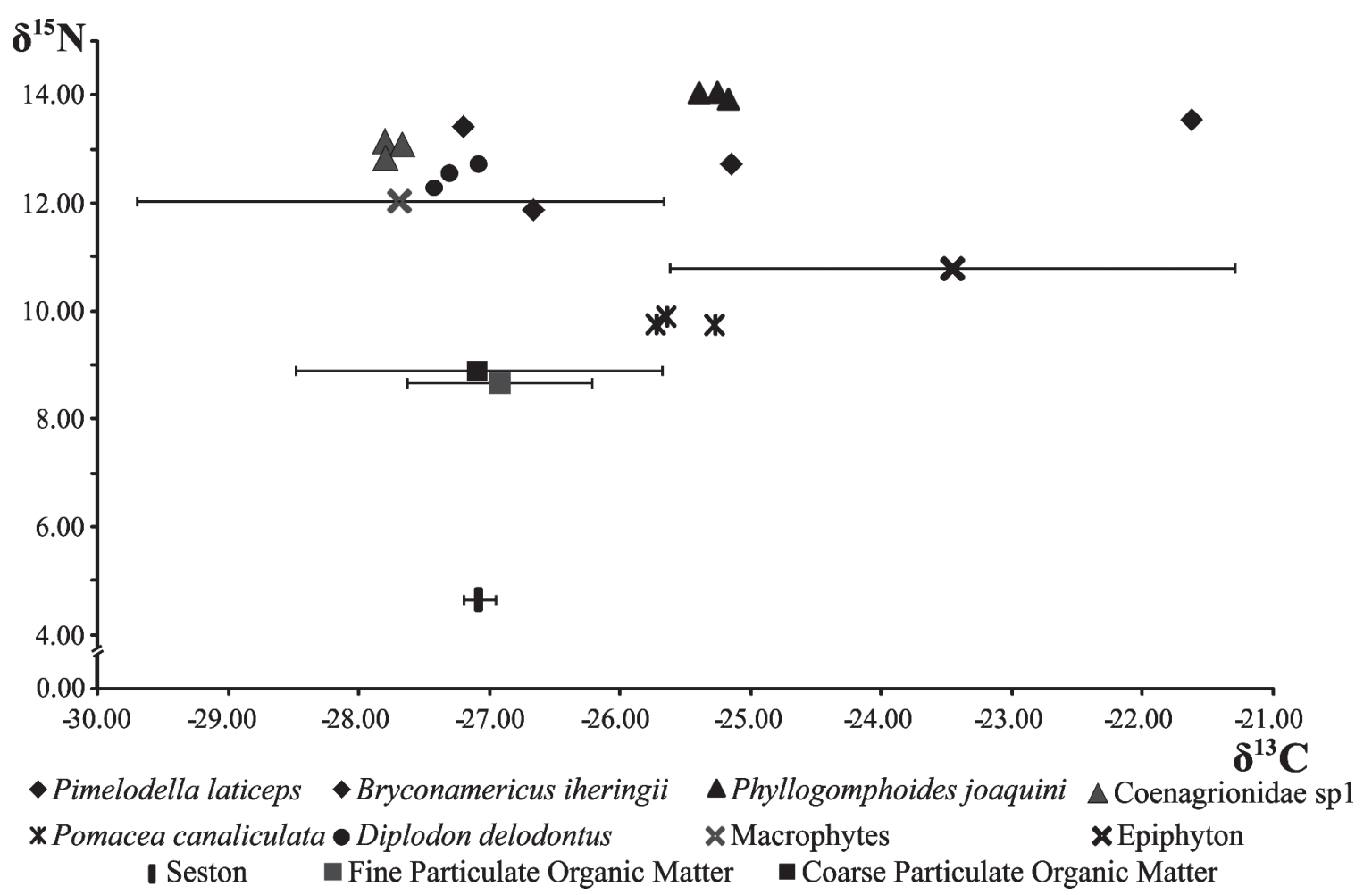

Fig. 12. Stable nitrogen and carbon isotopes in the taxonomic groups analyzed and in the basal resources available in La Choza stream during 2007-2008. Bars represent standard deviations of the carbon isotopes in basal resource. 
because the siliceous frustules are very resistant. In the Coenagrionidae, besides the usual animal remains, vascular plants were occasionally found. The presence of such plant material could result from a coincidental acquisition at the moment of capture, or because vegetal matter had been present in the digestive tract of some herbivorous prey upon its ingestion. Because in this type of habitat the diversity of organisms is elevated, thus offering a greater number and diversity of potential prey (Chilton, 1990), the Coenagrionidae usually become associated with the aquatic macrophytes (MerRITT \& Cummins, 1996).

In general, the stable isotope values confirmed the results from the analyses of the digestive contents. The values for $\delta^{15} \mathrm{~N}$ were over $9 \%$ and were usually higher than the data reported by other authors for the Neotropical Region (WANTZEN et al., 2002; GARCÍA et al., 2006; Molina et al., 2011). These higher values would indicate that the macroinvertebrates analyzed here were omnivorous, with only $P$. joaquini being a predator. With respect to $\delta^{13} \mathrm{C}$, a comparison of the values for the taxa with those of the basal resources indicated, in nearly all instances, a correspondence to the data from the detritus, although $D$. delodontus figures were also associated with the seston range and $P$. joaquini data with the epiphyton values. In the case of $P$. canaliculata, was observed vegetal matter in the stomach contents however this was not confirmed by the analysis of stable isotopes. Probably this difference is due to macrophytes consumed by $P$. canaliculata no were the same as those that were collected for stable isotope analysis. These findings corroborate the results from the analyses of gut contents, thus demonstrating that the detritus was an important trophic resource for the most macroinvertebrates in La Choza stream. In addition, the isotope values obtained for other pampean streams likewise indicated that the Chironomidae had been feeding mainly on detritus (Lopez van Oosterom, pers. obs.).

Both of the fish species analyzed fed on an ample range of food items, often spanning several trophic levels and including the macroinvertebrates as a major food resource because of their abundance in this temperate stream. The diet of the small characid B. iheringii has been described in the literature as omnivorous; consisting of microcrustaceans, the larvae of insects, and a vegetal fraction that is highly variable and depends on the type of environment (DestéFANIS \& FrEYRE, 1972; Escalante, 1983, 1987; Grosman et al., 2000; LóPez CAzorla et al., 2003). The information on P. laticeps is scarce, with the only reference for Argentina pertaining to a shallow lake (DestÉFAnis \& FreYre, 1972). There, chironomid larvae and microcrustaceans constituted the main base of that fish's diet, with Palaemonetes sp. and the Ostracoda being complementary components. We wish to emphasize here that, in view of the difference in the trophic diversity and diet variation from one year to the next in La Choza stream, both of these species exhibited an opportunistic generalist feeding strategy. The analysis of the gut contents indicated that both species notably exhibit invertivorous feeding. The sole $\delta^{15} \mathrm{~N}$ value for $B$. iheringii and the range for $P$. laticeps would be consistent with both species as being predators. The analysis of the stomach contents of $B$. iheringii, however, indicated an appreciable consumption of filamentous algae. This species had a $\delta^{13} \mathrm{C}$ value corresponding to the upper value observed for the epiphyton and therefore suggesting this vegetal matter as the main carbon source. On the contrary, $P$. laticeps exhibited a preference for the consumption of invertebrate items. This species had $\delta^{13} \mathrm{C}$ values between those being within the range for organic matter. These values could have arisen from the previous ingestion by macroinvertebrate prey such as $P$. canaliculata and bivalves such as $D$. delodontus. The latter species was not identified in the stomach contents however was recorded Bivalvia consumption. The only literature reference to $P$. laticeps was for a lentic environment in southern Brazil, with estimated values similar to those found in this study (GARCíA et al., 2007). With respect to $B$. iheringii, our only $\delta^{15} \mathrm{~N}$ estimate turned out to be greater than the value obtained here for P. laticeps, where the gut-content analysis strongly suggested an invertivorous diet, thus indicating the need to verify the $\delta^{15} \mathrm{~N}$ data for $B$. iheringii in La Choza stream.

For grassland-prairie streams WILEY et al. (1990) proposed the longitudinal gradient inversion postulated by VANNOTE et al. (1980), with the existence of autotrophic production in the headwaters of those systems. In addition, the significance of autochthonous food to the consumers present in the small shaded streams in northeastern Puerto Rico (MARch \& Pringle, 2003), southeastern Brazil (Moulton et al., 2004; FuentesBRITO et al., 2006), and tropical Asia (SAlAS \& DUdGEON, 2001; Mantel et al., 2004; YAm \& Dudgeon, 2005) has been postulated. The characteristics of La Choza stream are also consistent with the proposal by WILEY et al. (1990) since the basal resources of consumers, as confirmed by stable-isotope analysis, are mainly algae and the detritus from aquatic vegetation. Accordingly, in the sampling site is observed collector species dominance (gathering and filterering) and absence of the shredder within macroinvertebrate assemblage. However, prairie and pampean streams exhibit some differences. On the one hand, Pampean streams have high basal nutrient concentrations (ARTIGAS et al., 2013). Moreover, they contain macrophytes that are usually native and play a key role in structuring the biological community (GIORGI et al., 2005), unlike many of the streams in the plains of New Zealand where the invasive species Egeria densa has become dominant (CHAMPION \& TANNER, 2000).

In the La Choza stream the food chains described here were short, with a marked tendency towards omnivorousness, which circumstance would indicate 
that the food webs are diffuse and highly interconnected. Because of their prevalence and feeding mode, the gathering collectors play a crucial role in the food webs of these streams and as such represent a major link between the basal resource and the top consumer levels (MotTA \& UIEDA, 2004). This concept is in coincidence to the results observed in the trophic relationships studied at La Choza stream, where the particulate organic matter constitutes a predominant unlimited food resource with its resulting influence upon the biotic community.

Acknowledgements. This study was supported by the BBVA Foundation's GlobRio Proyect (Global changes in fluvial systems: effects on biodiversity, food web, and system functions) and CONICET. This is Scientific Contribution $N^{\circ} 911$ from the Instituto de Limnología “Dr. Raúl A. Ringuelet" (CONICET La Plata-UNLP). We wish to thank to Mónica Caviglia and Dr. Donald F. Haggerty, a retired career investigator and native English speaker, for editing the final version of the manuscript. We are especially grateful to Claudia Feijoó and collaborators (Universidad Nacional de Luján) for providing unpublished data of stable isotopes of the basal resources.

\section{REFERENCES}

Allan, J. D. \& Castillo, M. M. 2007. Stream Ecology. Structure and function of running waters. Dordrecht, Springer. 379p.

Almirón, A. E.; García, M. L.; Menni, R. C.; Protogino, L. C. \& Solari, L. C. 2000. Fish ecology of a seasonal lowland stream in temperate South America. Marine \& Freshwater Research 51:265-274.

Amundsen, P. A.; Gabler, H. M. \& StaldviK, F. J. 1996. A new approach to graphical analysis of feeding strategy from stomach contents data - modification of the Costello (1990) method. Journal of Fish Biology 48(4):607-614

Artigas, J.; García-Berthou, E.; Bauer,D. E.; Castro, M. I.; Cochero, J.; Colautti, D.; Cortelezzi, A.; Donato, J. C.; Elosegi, A.;Feioó, C.; Giorgi, A.; Gómez, N.; LegGieri,L.; MuÑoz, I.; Rodrigues-Capítulo, A.; Romaní, A. M. \& Sabater,S. 2013. Global pressures, specific responses: effects of nutrient enrichment in streams from different biomes. Environmental Research Letters 8:1-13. Available in: $<$ http://iopscience.iop. org/1748-9326/8/1/014002/pdf/1748-9326_8_1_014002.pdf>. Accessed on: 04.03.2013

Berg, H. B. 1995. Chapter VII, Larval food and feeding behaviour. In: Armitage, P. D.; Cranston, P. S. \& Pinder, L. C. V. eds. The Chironomidae: biology and ecology of non-biting midges. London, Chapman \& Hall. p.136-168.

Bonetto, A. A. \& TASSARA, M. 1987. Notas sobre el conocimiento limnológico de los gasterópodos paranenses y sus relaciones tróficas. I Ampullariidae. Ecosur 14:55-62

CazZaniga, N. J. \& Estebenet, A. L. 1984. Revisión y notas sobre los hábitos alimentarios de los Ampullariidae (Gastropoda). Historia Natural 4(22):213-224.

Champion, P. D. \& Tanner, C. C. 2000. Seasonality of macrophytes and interaction with flow in a New Zealand lowland stream. Hydrobiologia 441:1-12.

Chilton, E. W. 1990. Macroinvertebrate communities associated with 3 aquatic macrophytes (Ceratophyllum demersum, Myriophyllum spicatum and Vallisneria americana) in lake Onalaska, Wisconsin. Journal of Freshwater Ecology 5:455-466.

Colautti, D. C.; Maroñas, M. E.; Sendra, E. D.; Protogino, L. C.; Brancolini, F. \& Campanella, D. 2009. Ictiofauna del Arroyo La Choza, cuenca del Río de la Reconquista (Buenos Aires, Argentina). Biología Acuática 26:55-62.

Cummins, K. W.; Merritt, R. W. \& Andrade, P. C. N. 2005. The use of invertebrate functional groups to characterize ecosystem attributes in selected streams and rivers in south Brazil. Studies on Neotropical Fauna and Environment 40(1):69-89.

DeNiro, M. J. \& Epstein, S. 1981. Influence of the diet on the distribution of nitrogen isotopes in animals. Geochimica et Cosmochimica Acta 45:341-351.
Destéfanis, S. \& Freyre, L. R. 1972. Relaciones tróficas de los peces de la laguna de Chascomús con un intento de referenciación ecológica y tratamiento bioestadístico del espectro trófico. Acta Zoológica Lilloana XXIX:17-33.

DíaZ-Villanueva, V. \& Albariño, R. 1999. Feeding habit of Notoperla archiplatae (Plecoptera) larvae in a North Patagonia Andean stream, Argentina. Hidrobiologia 412:43-52.

Di Marzio, W.; Tortorelli, M. \& Freyre, L. 2003. Diversidad de peces en un arroyo de llanura. Limnetica 22(3-4):71-76.

Escalante, A. H. 1983. Contribución al conocimiento de las relaciones tróficas de peces de agua dulce del área platense. II Otros Tetragonopteridae. Limnobios 2(7):311-322.

1987. Dieta comparativa de Cheirodon interruptus interruptus (Osteichthyes, Characidae) en ambientes lénticos y lóticos de la provincia de Buenos Aires. Revista del Museo de La Plata (Nueva Serie), Zoología 14:35-45.

Estebenet, A. L. 1995. Food and feeding in Pomacea canaliculata (Gastropoda: Ampullariidae). Veliger 38:277-283.

Estebenet, A. L. \& Martín, P. R. 2002. Pomacea canaliculata (Gastropoda: Ampullariidae): Life-history traits and their plasticity. Biocell 26:83-89.

Feijoó C. S. \& Lombardo, R. J. 2007. Baseline water quality and macrophyte assemblages in Pampean streams: a regional approach. Water Research 41(7):1399-1410.

FERnándeZ, H. \& Domínguez, E. 2001. Guía para la determinación de los artrópodos bentónicos sudamericanos. San Miguel de Tucumán, EudeT (Serie: Investigaciones de la UNT).

FernándeZ, E.; Ferriz, R.; Bentos, C.\& LóPeZ, G. 2008. Ichthyofauna of two streams in the high basin of the Samborombón River, Buenos Aires province, Argentina. Revista Museo Argentino de Ciencias Naturales 10(1):147-154.

Fuentes-Brito, E.; Moulton, T. P.; De Souza, M. L. \& Bunn, S. E. 2006. Stable isotope analysis indicates microalgae as the predominant food source of fauna in a coastal forest stream, south-east Brazil. Austral Ecology 31(5):623-633.

García, A. M.; Hoeinghaus, D. J.; Vieira, J. P. \& Winemiller, K. O. 2007. Isotopic variation of fishes in freshwater and estuarine zones of a large subtropical coastal lagoon. Estuarine, Coast Shelf Science 73(3-4):399-408.

García, A. M.; Hoeinghaus, D. J.; Vieira, J. P.; Winemiller, K. O.; Motta Marques, D. M. L. \& Bemvenuti, M. A. 2006 Preliminary examination of food web structure of Nicola Lake (Taim Hydrological System, south Brazil) using dual C and $\mathrm{N}$ stable isotope analyses. Neotropical Ichthyology 4(2):279-284.

Giorgi, A.; Feijoó C. \& Tell, G. 2005. Primary producers in a Pampean stream: temporal variation and structuring role. Biodiversity and Conservation 14:1699-1718.

Grosman, F.; González, G.; Agüeria, D. \& Sanzano, P. 2000. Ictiología del "Lago Municipal de Colón" (Argentina), como un ejemplo de dinámica ambiental. AquaTic 10. Available at: $<$ http://www.revistaaquatic.com/aquatic/art.asp?t=h\&c=85> Accessed on: 11.12.2012.

JaArsma, N.; De Boer, S.; Townsend, C.; Thompson, R. \& Edwards, E. 1998. Characterising food-webs in two New Zealand streams New Zealand Journal of Marine and Freshwater Research 32:271-286.

Lara, G.; Parada, E. \& Peredo, S. 2002. Alimentación y conducta alimentaria de la almeja de agua dulce Diplodon chilensis (Bivalvia Hyriidae). Gayana Zoología 66(2):107-112.

Lau, D.; Leung, K. \& Dudgeon, D. 2009. What does stable isotope analysis reveal about trophic relationships and the relative importance of allochthonous and autochthonous resources in tropical streams? A synthetic study from Hong Kong. Freshwater Biology 54:127-141

López Cazorla, A.; Durán, W. \& Tejera, L. 2003. Alimentación de la ictiofauna del río Sauce Grande, provincia de Buenos Aires, Argentina. Biología Acuática 20:73-79.

Mantel, S. K.; Salas, M. \& Dudgeon, D. 2004. Foodweb structure in a tropical Asian forest stream. Journal of North American Benthology Society 23(4):728-755.

March, J. G. \& Pringle, C. M. 2003. Food web structure and basal resource utilization along a tropical island stream continuum, Puerto Rico. Biotropica 25:84-93.

Merritt, R. W. \& Cummins, K. W. 1996. An introduction to the aquatic insects of North America. Kendall, Hunt Publishing 
Company.

MinagaWA, M. \& WADA, E. 1984. Stepwise enrichment of $15 \mathrm{~N}$ along food chains: Further evidence and the relation between $\delta 15 \mathrm{~N}$ and animal age. Geochimica et Cosmochimica Acta 48:1135-1140.

Molina, C. I.; Gibon, F. M; Oberdorff, T.; Dominguez, E.; Pinto, J.; Marín, R. \& Roulet, M. 2011. Macroinvertebrate food web structure in a floodplain lake of the Bolivian Amazon. Hydrobiologia 663:135-153.

Motta, R. \& Uieda, V. 2004. Diet and trophic groups of an aquatic insect community in a tropical stream. Brazilian Journal of Biology 64(4):809-817.

Moulton, T. P.; De Souza, M. L.; Silveira, R. M. L.; Felipe, A. M. \& Krsulovic, F. A. M. 2004. Effects of ephemeropterans and shrimps on periphyton and sediments in a coastal stream (Atlantic forest, Rio de Janeiro, Brazil). Journal of North American Benthology Society 23(4):868-881.

Muñoz, I.; Romaní, A.; Rodríguez Capítulo, A.; González Esteban, J. \& García-Berthou, E. 2009. Capitulo XIX, Relaciones tróficas en el ecosistema fluvial. In: Elosegui, A. \& Sabater, S. eds. Conceptos y técnicas para el estudio de la ecología de ríos. Barcelona, Fundación BBVA. p. 359-362.

Ocón, C. S. \& Rodrigues Capítulo, A. 2004. Presence and abundance of Ephemeroptera and other sensitive macroinvertebrates in relation with habitat conditions in pampean streams (Buenos Aires, Argentina). Archiv für Hydrobiologie 159(4):473-487.

PARODI, L. R. 1942. ¿Por qué no existen bosques naturales en la llanura bonaerense? Revista del centro de estudiantes de la facultad de Agronomía de la Universidad Nacional de Buenos Aires 30:387-390.

Peterson, B. J. \& Fry, B. 1987. Stable isotopes in ecosystem studies. Annual Review of Ecology and Systems 18:293-320.

Remes Lenicov, M.; Colautti, D. C. \& López, H. L. 2005. Ictiofauna de un ambiente lótico suburbano: el arroyo Rodríguez (Buenos Aires, Argentina). Biología Acuática 22:223-230.

Rodrigues Capítulo, A.; OCón, C. S. \& TANGorra, M. 2003. Una visión bentónica de los ambientes lóticos del NE de la provincia de Bs. As. Biología Acuática 21:1-4.

Rodrigues Capítulo, A.; Paggi, A. C.\& Ocón, C. S. 2002.Zoobenthic communities in relation to slope, substrate heterogeneity and urban disturbances in Pampean hill streams (Argentina). Verhandlungen des Internationalen Verein Limnologie 28:1267-1273.

Rodrigues Capítulo, A.; Tangorra, M. \& Ocón, C. S. 2001. Use of benthic macroinvertebrates to assess the biological status of Pampean streams in Argentina. Aquatic Ecology 35:109-119.

Rodrigues Capítulo, A.; Gómez, N.; Giorgi, A. \& Feijoó, C. 2010. Global changes in pampean lowland streams (Argentina): implications for biodiversity and functioning. Hidrobiologia 657(1):53-70.

Salas, M. \& Dudgeon, D. 2001. Stable-isotope determination of mayfly (Insecta: Ephemeroptera) food sources in three tropica Asian streams. Archiv für Hydrobiologie 151:17-32.

TownSEND, C. 1996. Invasion biology and ecological impacts of brown trout Salmo trutta in New Zealand. Biological Conservation 78(1-2):13-22.

VANDER Zanden, M. J. \& RASMUSSEN, J. B. 2001. Variation in $\delta 15 N$ and $\delta 13 \mathrm{C}$ trophic fractionation: Implications for aquatic food web studies. Limnology and Oceanography 46(8):2061-2066.

Vannote, R.; Minshall, G.; Cummings, K.; Sedell, J. \& Cushing, C. 1980. The river continuum concept. Canadian Journal of Fisheries and Aquatic Science 37:130-137

WAllace, J. \& Webster, J. 1996. The role of macroinvertebrates in stream ecosystem function. Annual Review of Entomology 41:115-139.

Wantzen, K. M.; de Arruda Machado, F.; Voss, M.; Boriss, H. \& Junk, W. J. 2002. Seasonal isotopic shifts in fish of the Pantanal wetland, Brazil. Aquatic Science 64(3):239-251.

Wiley, M.; Osborne, L. \& LARIMORE, R. 1990. Longitudinal structure of an agricultural prairie system and its relationship to curren stream ecosystem theory. Canadian Journal of Fisheries and Aquatic Science 47:373-384

Winterbourn, M.; Cowie, B. \& Rounick, J. 1984. Food resources and ingestion patterns of insects along a West Coast, South Island river system. New Zealend Jornal of Marine and Freshwater Research 18(1):43-51.

Yam, R. S. W. \& Dudgeon, D. 2005. Streams Stable isotope investigation of food use by Caridina spp. (Decapoda: Atyidae) in Hong Kong streams. Journal of North American Benthology Society 24(1):68-81. 